\title{
Study on the Evaluation of Performance for Pitch Pine Round Timbers as Safety Barrier Beam Members*1
}

\author{
Jinah Lim*2, Hwanmyeong Yeo*3, and Jun-Jae Lee*3†
}

\begin{abstract}
In this study, bending test was conducted as beam members in timber roadside safety barrier. The flexural properties of pitch pine round timber according to the diameters were evaluated. And then grading based on the growth characteristics applied to choosing the pitch pine round timbers which is met the criteria of guideline (Japan, 2008). MOR of round timber $160 \mathrm{~mm}$ is higher than other specimens from 100 $\mathrm{mm}$ to $140 \mathrm{~mm}$. Because of lower juvenile wood ratio and higher density. The MOE of round timber is decreased according to the increment of diameter. Only $32 \%$ of the specimens has passed the limitations. Performance of pitch pine round timbers has confirmed to suitability roadside safety beam members according to the guideline (Japan, 2008).
\end{abstract}

Keywords : pitch pine round timber, safety barrier, bending moment, visual grading

\section{INTRODUCTION}

In a number of countries, including the Netherlands and USA, timber safety barriers are being considered as alternatives to the traditional steel safety barriers (Leijten, 2001). In Japan, safety barriers consisting of wood beams and concrete posts have been installed along the roads. The performance of each safety barrier member was evaluated using a static test according to the guideline of safety barrier in Japan and was demonstrated through the crash test (Zhang et al., 2004). These timber safety barriers qualified have been installed in many countries (Bligh and Bullard, 1995; Malo, 2004). However the timber safety barriers for roadside safety have never before been installed in Korea.

In 1911, pitch pine (Pinus rigida Mill) was first planted in Suwon to prevent insect damage to the trees and to treeless mountains. Now, pitch pine is planted all over the country and grows on a total of approximately 480,000 ha. Of the 480,000 ha of pitch pines, 420,000 ha have reached or will reach maturity soon. Also, the strength properties of pitch pines are greater than those of other domestic conifers, but the presence of knots and resin in lumber make

*1 Received on March 28, 2011; accepted on July 11, 2011

*2 Department of Forest Sciences, College of Agriculture and Life Science, Seoul National University, Seoul 151-921, Korea

*3 Department of Forest Sciences, Research Institute for Agriculture and Life Sciences, College of Agriculture and Life Science, Seoul National University, Seoul 151-921, Korea

† Corresponding author : Jun-Jae Lee (e-mail: junjae@snu.ac.kr) 
Study on the Evaluation of Performance for Pitch Pine Round Timbers as Safety Barrier Beam Members

Table 1. Numbers of test specimen

\begin{tabular}{ccc}
\hline $\begin{array}{c}\text { Diameter } \\
(\mathrm{mm})\end{array}$ & $\begin{array}{c}\text { Length } \\
(\mathrm{mm})\end{array}$ & $\begin{array}{c}\text { Sample numbers } \\
(\mathrm{n})\end{array}$ \\
\hline \hline 100 & 2,400 & 19 \\
120 & & 46 \\
140 & & 23 \\
160 & & 9 \\
\hline Total & & 97 \\
\hline
\end{tabular}

them a substandard structural material. So far, most pitch pine has been used as a raw material for pulp, boards and pellets. Kim et al. (2007) carried out research on development of pitch pine glulam. It was found that medium-diameter logs, 15 to $30 \mathrm{~cm}$ in the top end diameter, was occupied greater than about $90 \%$. Also, pitch pines showed a higher percentage of Grade 2 logs than any other log character grade. Based on these results, Kim et al. (2007) reasonably concluded that pitch pine with a breast height diameter less than $23 \mathrm{~cm}$ could be used as raw material for medium density fibreboard (MDF) but not as structural lumber or glued laminated timber.

The round log require less processing than other uses, produce less waste than lumber production. Round members are needed a smaller volume of logs than lumber production. Also, bending moment capacity is a function of a section property called section modulus (SM), and resistance to bending displacement is directly related to the moment of inertia. In addition to advantages derived from geometry, round timber has strength advantages derived from grain orientation due to the surface continuity of the wood fibers. In round timber, fibers flow continuously around knots on the surface (Wolfe, 2000). Because of these and other advantageous characteristics, we suggested round shape for a timber safety barrier beam member.

The aims of this study are to provide data on the bending properties of pitch pine round timber, and to evaluate the performance of pitch pine round timber as safety barrier beam members. And based on the effects of growth characteristics derived from pinch pine, pitch pine round timbers classify to satisfaction for safety barrier beam members. These preliminary data are help to design and to selection for safety barrier beam members.

\section{MATERIALS and METHODS}

\subsection{Materials}

Pitch pine (Pinus rigida Mill) trees were obtained from a plantation forest in Jeollanam-do, South Korea. A top end diameter among 160 and $220 \mathrm{~mm}$ was observed in $86 \%$ of logs. Most of the pitch pine log turned up medium diameter log according to the log specification No. 2007-02 (KFRI, 2007). The trunk of each tree was cut into logs $2.4 \mathrm{~m}$ in length, which were then selected for processing based on end-diameter. After being cutting, the logs were sawed into a rectangular form and then processed circularly. The pitch pine round timber stacked off during the 6 months in the room. Round timbers with a diameter of 100, 120, 140 and $160 \mathrm{~mm}$ were processed finally. The dimensions and sizes for each specimen are presented in Table 1.

\subsection{Static Bending Test}

\subsubsection{Bending Test}

The static bending test procedure was a hybrid of ASTM D 198 (2006) and guideline of Japan Road Association (Japan Road Association, 2008). The round timber supports were simply supported and loaded at center point on a span. The static bending test was conducted on a $2 \mathrm{~m}$ 
Table 2. Standard design and optimum dimensions of safety barriers

\begin{tabular}{|c|c|c|c|c|c|c|c|}
\hline \multirow{4}{*}{ Type } & \multicolumn{4}{|c|}{ Japan Road Association* } & \multicolumn{3}{|c|}{$\begin{array}{c}\text { Ministry of Construction and } \\
\text { Transportation** }\end{array}$} \\
\hline & \multicolumn{4}{|c|}{ Beam ultimate bending moment $(\mathrm{kN} \cdot \mathrm{m})$} & \multirow{3}{*}{$\begin{array}{l}\text { Impact Severity } \\
\qquad(\mathrm{kJ})\end{array}$} & \multirow{3}{*}{ Type } & \multirow{3}{*}{$\begin{array}{l}\text { Impact Severity } \\
(\mathrm{kJ})\end{array}$} \\
\hline & \multirow{2}{*}{ Total } & \multirow{2}{*}{$\begin{array}{l}\text { Main } \\
\text { beam }\end{array}$} & \multicolumn{2}{|c|}{ Sub-beam } & & & \\
\hline & & & One & One or more & & & \\
\hline $\mathrm{C}$ & 23 & 17 & 6 & 4.0 & 45 & SB1 & 60 \\
\hline B & 26 & 17 & 9 & 4.5 & 60 & SB2 & 90 \\
\hline A & 50 & 36 & 14 & 7.0 & 130 & SB3 & 130 \\
\hline $\mathrm{SC}$ & 66 & 49 & 17 & 8.5 & 160 & SB4 & 160 \\
\hline SB & 89 & 68 & 21 & 10.5 & 280 & SB5 & 230 \\
\hline SA & 110 & 68 & 42 & 21.0 & 420 & SB6 & 420 \\
\hline
\end{tabular}

* Installation Guideline of Roadside Safety Barrier. 2008. Japan

** Installation and Maintenance Guideline for Roadside Safety Appurtenance - Vehicle Restraint System. 2001. Korea

span using a Universal Testing Machine (Zwick, $10 \mathrm{t}$ ) at a loading rate of $15 \mathrm{~mm} / \mathrm{min}$.

Modulus of Rupture (MOR) was calculated at the ultimate load according to the equation [1].

$$
M O R=\frac{M y}{I}
$$

where,

$M$ : the bending moment $(\mathrm{kN} \cdot \mathrm{m})$

I: the moment of inertia $\left(\mathrm{mm}^{4}\right)$

$y$ : the distance from the neutral axis $(\mathrm{mm})$

Modulus of Elasticity (MOE) was calculated according to the equation [2],

$$
M O E=\frac{P L^{3}}{48 \triangle I}
$$

where,

$P$ : the difference between the load within the proportional limit $(\mathrm{N})$

$L$ : the beam span $(\mathrm{mm})$

$\triangle$ : the displacement at the midspan (mm)

I: the moment of inertia $\left(\mathrm{mm}^{4}\right)$

\subsubsection{Moisture Contents (MC) and Specific Gravity (SG)}

Moisture contents (MC) and specific gravity (SG) samples were collected near the location of failure immediately after testing. The disks taken from each $\log$ to measure $\mathrm{MC}$ and $\mathrm{SG}$ were scanned later to determine other growth characteristics such as growth rate and the percentage of the cross section that was juvenile wood. The specimens MC and SG were measured according to ASTM D 2395 and D 4442 (ASTM, 2006), respectively. The average specific gravity of the specimen was $0.48( \pm 0.05)$, and the average moisture content of the specimen was $16.6 \%( \pm 3.0)$.

\subsection{Estimation of Performance as Safety Barrier Beam Members}

The guideline are presented in Table 2 that roadside safety barrier have to meet standard design value and optimum dimension (Japan road Association, 2008). The test condition on the type of roadside safety barrier in Japan is 


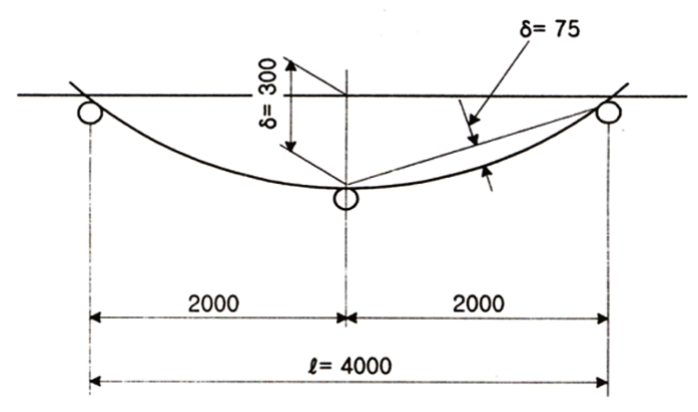

Fig. 1. Deformation of safety barrier (Unit: $\mathrm{mm}$ ).

different from that of the Korea. The performance of safety barrier was compared both of the Impact Severity (IS) which the kinetic energy in a collision is in directly.

Ultimate bending moment of safety barrier beam is calculated from the test results of static bending test and is regarded to deform as shown in the Fig. 1 during car crash. It is a ultimate bending moment in the plastic region up to $75 \mathrm{~mm}$ substituting load-deformation curve of static bending test with linear model (Fig. 2).

\subsection{Application of Visual Grading Rule for Round Timber as Safety Barrier Beam Members}

Research of round timber is in progress for use as pile, pole and log home members. ASTM Standard D 3957 (ASTM, 2006) provides the procedures for establishing stress grades for structural members used in log home. The standard addresses grading and property assignment for two types of structural members used in log buildings: wall logs and round timber beams. Properties of two types of round timber beams, unsawn and sawn round timbers, are addressed in ASTM D 3957. The only grade assigned to unsawn round timbers in "unsawn", and this timber grade is primarily intended for bending or truss members. Unsawn

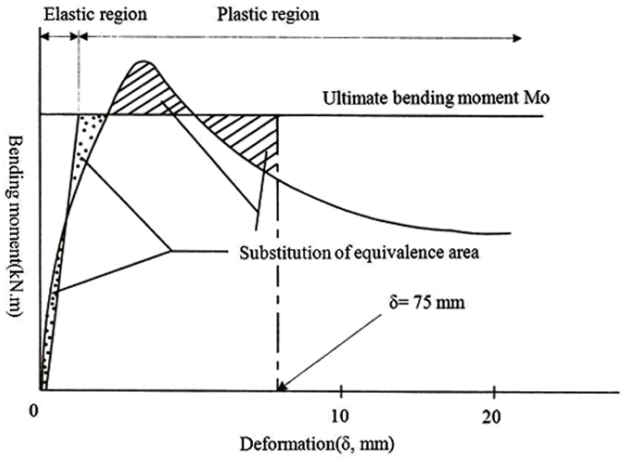

Fig. 2. Determination methods of performance for beam members.

round timbers used in the superstructure of buildings are covered by specification and test methods detailed in ASTM D 3200 (2006). Unlike conventional sawn timber, which is classified according to visual appearance attributes, there is only one stress grade for poles or piles (ASTM D 25, 2006). this standard give minimum quality requirements and size classifications for round timber piles, poles, and construction $\log$.

As with the visual grades of dimension lumber or structural timbers, the grade description of structural logs is a combination of limits on characteristics that affect strength and characteristics that might affect serviceability for the intended application, but not necessarily strength. Because visual grading rule of round timber did not exist in Korea, methods measured visual characteristics is referred to ASTM D 25 (2005). The knot diameter was measured around the circumference of the timber, i.e., at a right-angle to the longitudinal direction of the specimen (Fig. 3). Locations and sizes of knots, not including callus tissue, along the length of the round timber were recorded in all specimens. In knot cluster, all of the knots within a longitudinal distance of $150 \mathrm{~mm}$ were included. 
Jinah Lim, Hwanmyeong Yeo, and Jun-Jae Lee

Table 3. Flexural properties of pitch pine round timbers according to diameter

\begin{tabular}{cccccc}
\hline $\begin{array}{c}\text { Diameter } \\
(\mathrm{mm})\end{array}$ & $\mathrm{SG}^{*}$ & $\begin{array}{c}\mathrm{RJW}^{* *} \\
(\%)\end{array}$ & \multicolumn{2}{c}{$\begin{array}{c}\text { MOR } \\
(\mathrm{MPa})\end{array}$} & $\begin{array}{c}\text { MOE } \\
(\mathrm{MPa})\end{array}$ \\
\hline \hline 100 & $0.47(0.05)$ & 100.0 & 51.1 & $(10.7)^{* * *}$ & $7,350.8(1,124.0)$ \\
120 & $0.46(0.03)$ & 100.0 & 48.6 & $(10.9)$ & $6,400.3(1,123.5)$ \\
140 & $0.47(0.04)$ & 91.3 & 49.8 & $(14.2)$ & $6,160.2(1,077.4)$ \\
160 & $0.51(0.04)$ & 78.1 & 61.0 & $(7.8)$ & $5,684.1(685.7)$ \\
\hline Total & $0.48(0.05)$ & - & 51.4 & $(11.6)$ & $6,454.4(1,168.0)$ \\
\hline
\end{tabular}

* Specific Gravity

** Ratio of Juvenile Wood

*** Standard deviation

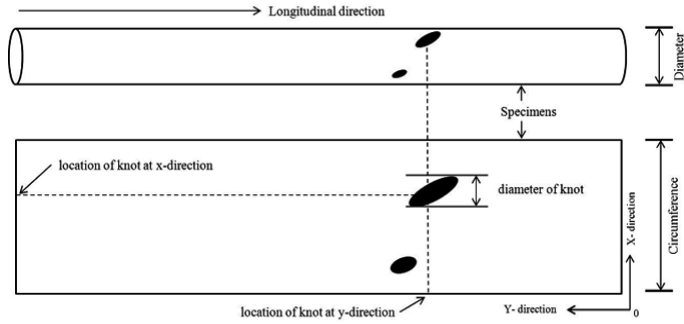

Fig. 3. Method used to determined knot property.

\section{RESULTS and DISCUSSION}

\subsection{Flexible Properties of Round Timber}

The testing of mechanical properties was performed in order to determine the strength and stiffness of pitch pine round timber according to the diameter (Table 3). The MOR of the 160 $\mathrm{mm}$ diameter timber was higher about $20 \%$ than those of other diameters of pitch pine round timber. Pitch pine round timber $160 \mathrm{~mm}$ in diameter had and approximately $8.5 \%$ higher density than the average value. As shown Table 3 , the percentage of juvenile wood in the pitch pine specimens ranged from $78.1 \%$ to $100 \%$. Most researchers agree that the 20 annual rings counted outward from the pith indicate juvenile wood, depending on the tree species and prop- erty studies (Voorhies and Groman, 1969; Wolfe, 2000). Compared to mature wood, the juvenile wood of conifers is characterized by low density, shorter and thinner tracheids, more tracheids per unit area, larger microfibril angle, less transverse shrinkage, considerably greater longitudinal shrinkage, lower strength and modulus of elasticity, smaller percentage of late wood, more compression wood, thinner cell walls, larger lumen diameters, and less cellulose and greater hemicellulose and lignin contents (Voorhies and Groman, 1969).

The correlation of MOR and pitch pine round timber diameter was not observed. Larson et al. (2004a, 2004b) conducted bending test on lodgepole pine logs. Although the relationship between MOR and diameter had an $\mathrm{r}^{2}$ value of 0.41 only butt log, the correlation including tip $\log$ is weakened as the percentage of juvenile wood increases.

The MOE measured for the pitch pine round timber in Table 3, in the $100 \mathrm{~mm}$ of timber diameter was $7,350.8 \mathrm{MPa}$. This is $13.9 \%$ greater than the average value of all diameters. In this study, larger round timbers had a tendency for lower MOE values. This decreasing tendency according to the timber diameter is consistent with other published reports (Ranta-manus, 1999) and lower MOE values for the larger logs can thus be attributed to a combination of bear- 
Study on the Evaluation of Performance for Pitch Pine Round Timbers as Safety Barrier Beam Members

Table 4. Bending moments of pitch pine round timber

\begin{tabular}{ccccc}
\hline \multirow{2}{*}{$\begin{array}{c}\text { Diameter } \\
(\mathrm{mm})\end{array}$} & \multicolumn{2}{c}{ Bending moment $(\mathrm{kN} \cdot \mathrm{m})$} \\
\cline { 2 - 5 } & \multicolumn{2}{c}{ Ultimate } & \multicolumn{3}{c}{ Max. } \\
\hline \hline 100 & 4.2 & $(0.9)^{*}$ & 5.0 & $(1.1)$ \\
120 & 7.1 & $(1.8)$ & 8.3 & $(1.8)$ \\
140 & 11.9 & $(3.3)$ & 13.3 & $(3.7)$ \\
160 & 22.4 & $(2.9)$ & 24.5 & $(2.9)$ \\
\hline
\end{tabular}

* Standard deviation

ing and shear deformations (Wolfe and Moseley, 2005).

The majority of pole failures involved knots on the under surface of the beam (Cerda and Wolfe, 2003). Most of the failures occurred on the side on which tension was applied and started grains. However, after the maximum load had been reached these round timbers were still able to support some load.

\subsection{Performance of Round Timber as Safety Barrier Beam Member}

Performance of round timber has been confirmed to determine suitability for roadside safety beam members. In Japan, Guideline is given the ultimate moment capacity for each members of every grade used a safety barrier (Table 4). Ultimate bending moment was calculated to be $75 \mathrm{~mm}$ using the moment-area method at the moment-displacement curve. Ultimate bending moment occupied $84.0 \sim 91.4 \%$ of maximum moment. The moment capacity of round timber was compared with guideline to ensure suitability for use in a safety barrier. Round timber, $160 \mathrm{~mm}$ in diameter, had a bending moment $22.4 \mathrm{kN} \cdot \mathrm{m}$ and could be used not only as a main beam of SB 2, but also as a sub-beam of SB 4 as shown in Table 2. The 100-, 120-, 140 $\mathrm{mm}$ diameter round timbers were determined to be suitable for uses as sub-beams under SB 2 .

\subsection{Grading of Round Timber as Safety Barrier Beam Member}

The possibility on utilization as safety barrier beam members was confirmed. However all of the specimens were not met the criteria of the safety barrier beam members. Visual grading were conducted for selecting from pitch pine round timbers which is met the criteria. Taking visual features into account, visual grading was conducted according to the ASTM D 25. Table 5 summarizes the visual grading result. Only $32.0 \%$ of the round timbers have been passed. The value accepted MOR and MOE of the unsawn grade are higher than those of the rejected round timbers, suggesting at least some ability of the visual grading system to separate the round timber into groups with distinct properties. In this study, a high percentage of rejection was seen with this grading system as a result of pitch pine growth characteristics, such as the fact that branches grow from a similar height around the tree. Branch arrangement of a whorl-branched conifer. Pines, spruces, and firs have whorled branches that from a circular pattern around the growing timber. The annual growth of a whorl branched conifer is determined by the number of shoots that are pre-formed in the buds. (Susan and Bonnie, 2009)

\section{CONCLUSION}

The flexural properties of pitch pine round timber were tested and evaluated the performance used to safety barrier beam member. And it is suggested that visual grading satisfied the minimum limitation of the beam member as safety barrier.

Because of lower juvenile wood ratio, MOR of round timber $160 \mathrm{~mm}$ is higher than other size specimens. There is a relationship between 
Jinah Lim, Hwanmyeong Yeo, and Jun-Jae Lee

Table 5. Visual grading of pitch pine round timber by ASTM D 25

\begin{tabular}{|c|c|c|c|c|c|c|c|c|}
\hline & \multirow[t]{2}{*}{ No. } & \multicolumn{3}{|c|}{$\begin{array}{l}\text { Ultimate bending moment } \\
\qquad(\mathrm{kN} \cdot \mathrm{m})\end{array}$} & \multicolumn{2}{|c|}{$\begin{array}{l}\text { MOR } \\
(\mathrm{MPa}) \\
\end{array}$} & \multicolumn{2}{|c|}{$\begin{array}{l}\mathrm{MOE} \\
(\mathrm{MPa}) \\
\end{array}$} \\
\hline & & \multicolumn{2}{|c|}{ Avg. } & Min. & & & & \\
\hline \multicolumn{9}{|c|}{ Accepted } \\
\hline 100 & - & & & - & - & - & - & - \\
\hline 120 & 13 & 7.9 & $(1.4)^{*}$ & 5.5 & 55.9 & $(7.2)$ & $6,709.3$ & $(1,117.9)$ \\
\hline 140 & 9 & 14.3 & (4.0) & 6.6 & 60.6 & (14.2) & $6,729.0$ & $(1,154.5)$ \\
\hline 160 & 9 & 22.4 & (2.9) & 18.9 & 61.0 & (7.8) & $5,684.1$ & (685.7) \\
\hline Total & 31 & \multicolumn{2}{|c|}{-} & - & 56.9 & (14.2) & $6,216.8$ & $(1,567.2)$ \\
\hline \multicolumn{9}{|c|}{ Rejected } \\
\hline 100 & 18 & 4.2 & (1.0) & 2.9 & 51.1 & (11.7) & $7,350.8$ & $(1,124.0)$ \\
\hline 120 & 32 & 6.8 & (1.8) & 2.5 & 45.7 & (10.8) & $6,274.7$ & $(1,118.8)$ \\
\hline 140 & 14 & 10.8 & $(2.0)$ & 6.9 & 43.4 & (8.1) & $5,794.5$ & (881.0) \\
\hline 160 & - & \multicolumn{2}{|c|}{-} & - & - & - & - & - \\
\hline Total & 66 & \multicolumn{2}{|c|}{-} & - & 46.7 & $(10.5)$ & $6,472.3$ & $(1,208.0)$ \\
\hline
\end{tabular}

( )* Standard deviation

MOE and round timber diameter with MOE tending to decrease with increasing round timber diameter. The mode of failure in pitch pine round timber occurs in a splintering tension. According to the guideline of the Japan, ultimate bending moment of round timber was compared and evaluated the performance. All of the round timber specimens is proper for beam members. It is possible that $160 \mathrm{~mm}$ of round timber is used main beam of SB2 sufficiently.

As a result of visual grading, the round timber with a diameter greater than $100 \mathrm{~mm}$ cannot be sufficiently used as main and sub-beam members in any safety barrier what is used in a timber safety barrier acquired to the minimum qualifications.

\section{ACKNOLEDGEMENT}

This study was carried out with the support of 'Forest Science \& Technology Projects (Project No. S120810L140120)' provided by Korea Forest Service.

\section{REFERENCES}

1. Kim, K. M., J. S. Park, S. T. Cho, W. S. Kim, K. B. Shim, S. R. Shim, J. A. Lim, and H. M. Yeo. 2007. Development and improvement of pitch pine glued laminated timber for structural use. Research Report 07-07. Korea Forest Research Institute.

2. Installation and Maintenance Guideline for Roadside Safety Appurtenance Vehicle Restraint System. 2001. Ministry of Construction and Transportation. 
Study on the Evaluation of Performance for Pitch Pine Round Timbers as Safety Barrier Beam Members

3. Notification No. 2007-02. Log Specification. 2007. Korea Forest Research Institute (KFRI).

4. Installation Guideline for Roadside safety barrier. 2008. Japan Road Association.

5. American Society for Testing and Materials (ASTM). 2005. D 25-99. Standard Specification for Round timber Piles.

6. American Society for Testing and Materials (ASTM). 2006. D 198-05. Standard Methods of Static Tests of Lumber in Structural Sizes.

7. American Society for Testing and Materials (ASTM). 2006. D 2395-02. Standard Test Methods for Specific Gravity of Wood and Wood-based Materials.

8. American Society for Testing and Materials (ASTM). 2006. D 3200-74. Standard Specification and Test Method for Establishing Recommended Design Stresses for Round Timber Construction Poles.

9. American Society for Testing and Materials (ASTM). 2006. D 3957-03. Standard Practice for Establishing Stress Grades for Structural Members Used in Log Homes.

10. American Society for Testing and Materials (ASTM). 2006. D 4442-92. Standard Test Methods for Direct Moisture Content Measurement of Wood and Wood-based Materials.

11. Bligh, R. P. and D. L. Bullard. 1995. Crash testing and evaluation of round, wood post, W-beam safety barrier system. Research Report 405391-1F.

12. Cerda, G. and R. Wolfe. 2003. Bending strength of chilean radiata pine poles. Forest Prod J. 53(4): $61 \sim 65$.

13. Larson, D., R. Mirth, and R. Wolfe. 2004a. The evaluation of small diameter ponderosa pine logs in bending. Forest Product Journal 54(12): 52 58.
14. Larson, D., R. Wolfe, and R. Mirth. 2004b. Small-diameter ponderosa pine roundwood in compression. Proceedings of 8th World Conference on Timber Engineering. Volume II. pp. 14 $\sim 17$.

15. Leijten, A. J. M. 2001. Impact crash and simulation of timber beams. Computational Methods and Experimental measurements X. WIT press, Southampton. pp. 859 868.

16. Malo, K. A. 2004. Impact Behaviour of roadside round wooden posts. Proceedings of the 8 th Word Conference on Timber engineering. pp. 283 $\sim 288$.

17. Ranta-Maunus, A. 1999. Round small-diameter timber for construction. Final report of project FAIR CT 92-0091 (VTT Publications No. 383). VTT Technical Research Centre of Finland.

18. Susan, C. F. and L. F. Bonnie. 2009. A guide to successful pruning, pruning evergreen trees. Virginia Tech. http://pubs.ext.vt.edu/430/430-457/ 430-457.html

19. Voohried, G. and D. A. Jameson. 1969. Fiber length in southwestern young-growth ponderosa pine. Forest Product Journal 19(5): 52 55.

20. Wolfe, R. 2000. Research challenger for structural use of small-diameter round timbers. Forest Products Journal 50(2): 19 21.

21. Wolfe, R. and C. Moseley. 2005. Strength of small-diameter round and tapered bending members. Forest Products Journal 55(3): 50 55.

22. Zhang, R., K. Kanemaru, T. Nakazawa, Y. Iimura, and M. Nakamura. 2004. Timber guardrail combined of round $\log$ rails and concrete posts. Proceedings of the 8th Word Conference on Timber Engineering. pp. 271 276. 